\section{Diagnosing PFAPA during the COVID-19 era: clarity during quarantine}

Periodic fever accompanied by aphthous stomatitis, pharyngitis and/or cervical adenitis (PFAPA) was first described in 1987 by Marshall et al. Fever periodicity is a hallmark of the diagnosis, and there is a noted absence of upper respiratory tract (URTI) symptoms and sick contacts. Diagnosing PFAPA can be challenging for clinicians. The most common treatment is corticosteroids, given at the first sign of fever. A single dose of prednisone will abort the febrile episode; this is unique to PFAPA and essentially diagnostic. ${ }^{12}$ Tonsillectomy has also been reported to be curative. $^{2}$

On 22 March 2020, New York State issued an executive 'stay-at-home' order due to the COVID-19 pandemic. This facilitated the diagnosis of PFAPA in our patient population. Travel and exposure to sick contacts, especially in day care, were markedly decreased, but a group of patients were still having periodic fevers. Furthermore, household members were not getting sick during these episodes.

A retrospective case-control study was performed at NYU Langone Hospital-Long Island using International Classification of Diseases 10th Revision (ICD-10) diagnosis codes (A68.9 (relapsing/recurrent fever]), M04.1 (periodic fever) and M04.8 (PFAPA)) to search for patients. Patients from 23 March 2020 to 1 November 2020 were selected as the 'quarantine' cohort, and patients from 1 January 2019 to 21 March 2020 served as controls. The primary outcome was time to diagnosis of PFAPA, defined as time from first visit to prescription of abortive corticosteroids.

Eight and nine patients were identified for the 'quarantine' and 'control' cohorts, respectively. There was a statistically significant difference in exposure to sick contacts and/or day care $(p<0.0004)$ and travel in the year prior $(\mathrm{p}<0.02)$ between groups (table 1$)$. Within the 'quarantine' cohort, time to diagnosis of PFAPA was shorter than the 'control' group (24 days vs 31 days, $\mathrm{p}<0.2$, figure 1 ). Adjusting for number of fever recurrences prior to initial visit, the 'quarantine' cohort was 2.7 times more likely to be diagnosed with PFAPA at a particular point in time compared with 'controls' $(\mathrm{HR}=2.74, \quad 95 \% \mathrm{CI}$ (0.87 to 8.62$), \mathrm{p}<0.08)$. 'Controls' had
Table 1 Demographics and clinical manifestations of the quarantine and control cohorts of patients with PFAPA

\begin{tabular}{|c|c|c|c|}
\hline Variable & $\begin{array}{l}\text { Quarantine group } \\
(\mathrm{n}=8)\end{array}$ & $\begin{array}{l}\text { Control group } \\
(\mathrm{n}=9)\end{array}$ & P value* \\
\hline Age in years, median (IQR) & $2.82(1.74-4.62)$ & $3.11(3.06-3.64)$ & 0.88 \\
\hline Male sex, $n(\%)$ & $3(37.5 \%)$ & $2(22.2 \%)$ & 0.62 \\
\hline $\begin{array}{l}\text { Family history of recurrence of: fevers, } \\
\text { aphthous ulcers and/or tonsillitis in first- } \\
\text { degree relative, } n(\%)\end{array}$ & $4(50 \%)$ & $6(66.6 \%)$ & 0.64 \\
\hline Presence of aphthous ulcers, $n(\%)$ & $1(12.5 \%)$ & $1(11.1 \%)$ & 1.00 \\
\hline Presence of pharyngitis, $n(\%)$ & $3(37.5 \%)$ & $2(22.2 \%)$ & 0.62 \\
\hline Presence of exudative pharyngitis, $n(\%)$ & $3(37.5 \%)$ & $4(44.4 \%)$ & 1.00 \\
\hline Presence of lymphadenopathy, $n(\%)$ & $5(62.5 \%)$ & $5(55.6 \%)$ & 1.00 \\
\hline $\begin{array}{l}\text { History of sick contacts and/or child care } \\
\text { centre attendance, } n(\%)\end{array}$ & $0(0 \%)^{*}$ & $8(88.9 \%)^{*}$ & $0.0004^{*}$ \\
\hline History of travel in past year, $n(\%)$ & $1(12.5 \%)^{*}$ & $5(55.6 \%)^{*}$ & $0.02^{*}$ \\
\hline Additional siblings at home, $n(\%)$ & $6(75.0 \%)$ & $6(66.7 \%)$ & 1.00 \\
\hline $\begin{array}{l}\text { Household (family) members getting sick } \\
\text { when subject is febrile? } n(\%)\end{array}$ & $0(0 \%)$ & $2(22.2 \%)$ & 0.32 \\
\hline
\end{tabular}

*As determined by Mann-Whitney test for continuous variables and Fisher's exact test for categorical variables, with statistical significance at $\mathrm{p}<0.05$

PFAPA, periodic fever accompanied by aphthous stomatitis, pharyngitis and/or cervical adenitis. an increased risk of diagnostic delay $(\mathrm{HR}=0.37 ; 95 \%$ CI $(0.12$ to 1.15$))$ and a larger IQR than the 'quarantine' cohort (0-57 vs 0-191, respectively).

A minimum of 5-6 months of documented periodic fevers is required to diagnose PFAPA. ${ }^{34}$ Some patients in our clinic had more than 6 months of documented fevers on presentation-these patients received steroids right away, while others were monitored. A similar study by $\mathrm{Ng}$ et al reported an increase in PFAPA cases during the pandemic, citing a lack of respiratory virus diversity. The authors report an increase in referrals to their clinic; our practice's numbers were consistent before and after pandemic. ${ }^{5}$

We take into account the limitations that come with any retrospective chart



Time (in days)

$\begin{array}{cccc} & \text { Quarantine Group } & \text { Control Group } & \text { P value } \\ \text { Median time to diagnosis, } & 24 \text { days }(0-57) & 31 \text { days }(0-191) & 0.2\end{array}$
in days (IQR)

Figure 1 Time to diagnosis of periodic fever accompanied by aphthous stomatitis, pharyngitis and/or cervical adenitis, ${ }^{1}$ defined as time from first visit with paediatric infectious diseases to prescription of steroids (used to abort febrile episodes). 
review, including incompleteness of coding systems, historian reporting and subsequent result bias. Our small sample size may have led to an overestimation of the quarantine's impact on diagnosis of PFAPA.

In the differential of recurrent fevers, viral infections (particularly URTIs) are always a consideration, particularly for those who attend day care. Without the outside impact of infectious exposures during the COVID-19 quarantine, the clinical picture of PFAPA was easier to ascertain. Physicians should consider PFAPA in a child with recurrent, periodic fevers lacking infectious exposures.

\section{Theresa Fiorito $\odot{ }^{1,2}$ Meredith Akerman, ${ }^{3}$ Asif Noor, ${ }^{1,2}$ Leonard R Krilov ${ }^{1,2}$}

${ }^{1}$ Pediatrics, NYU Langone Health, New York, New York, USA

${ }^{2}$ NYU Long Island School of Medicine, Mineola, New York, USA

${ }^{3}$ Biostatistics, NYU Langone Health, New York, New York, USA
Correspondence to Dr Theresa Fiorito, Pediatrics, NYU Langone Health, New York, NY 11501, USA; theresa.fiorito@nyulangone.org

Twitter Asif Noor @anoor82

Contributors Conception and design of the study/ review was performed by TF, MA and LRK. Data generation was performed by TF and MA. Analysis and interpretation of the data was performed by TF, AN, MA and LRK. Preparation or critical revision of the manuscript was performed by TF, AN, MA and LRK.

Funding The authors have not declared a specific grant for this research from any funding agency in the public, commercial or not-for-profit sectors.

Competing interests None declared.

Patient consent for publication Not applicable.

Provenance and peer review Not commissioned; externally peer reviewed.

(c) Author(s) (or their employer(s)) 2022. No commercial re-use. See rights and permissions. Published by BMJ.

\section{A) Check for updates}

To cite Fiorito T, Akerman M, Noor A, et al. Arch Dis Child Epub ahead of print: [please include Day Month Year]. doi:10.1136/archdischild-2021-323667
Accepted 29 January 2022

Arch Dis Child 2022;0:1-2. doi:10.1136/archdischild-2021-323667

ORCID iD

Theresa Fiorito http://orcid.org/0000-0003-27516819

\section{REFERENCES}

1 Marshall GS, Edwards KM, Butler J, et al. Syndrome of periodic fever, pharyngitis, and aphthous stomatitis. J Pediatr 1987;110:43-6.

2 Peridis S, Pilgrim G, Koudoumnakis E, et al. PFAPA syndrome in children: a meta-analysis on surgical versus medical treatment. Int J Pediatr Otorhinolaryngol 2010;74:1203-8.

3 Gattorno M, Hofer M, Federici S, et al. Classification criteria for autoinflammatory recurrent fevers. Ann Rheum Dis 2019:78:1025-32.

4 Renko M, Lantto U, Tapiainen T. Towards better diagnostic criteria for periodic fever, aphthous stomatitis, pharyngitis and adenitis syndrome. Acta Paediatr 2019:108:1385-92.

$5 \mathrm{Ng} \mathrm{KF}$, Morgan J, Cutts T, et al. Rise in children presenting with periodic fever, aphthous stomatitis, pharyngitis and adenitis syndrome during the COVID-19 pandemic. Arch Dis Child 2021;106:e49. 